\title{
MIXTURE DILUTION ON A NATURAL GAS SI ENGINE OPERATING AT LOW LOAD
}

\section{JIŘí VÁVRA, MICHAL TAKÁTS}

Czech Technical University in Prague, Technická 4, 16607 Praha 6, Czech Republic, Tel.: +420 264003 706, E-mail: jiri.vavra@fs.cvut.cz

Czech Technical University in Prague, Technická 4, 16607 Praha 6, Czech Republic, Tel.: +420 224351 827, E-mail: michal.takats@fs.cvut.cz STANI BOHAC

College of Engineering, University of Michigan, 1004 AL (W.E. Lay Auto Lab)

1231 Beal, Ann Arbor, Ml 48109-2133, (734)936-0431, E-mail: sbohac@umich.edu

\section{SHRNUTí}

V článku je prezentován výsledek experimentálního průzkumu spalování zředěné směsi zemního plynu se vzduchem při nízkém zatížení zážehového motoru. Zředění směsi vzduchem a recirkulujícími spalinami bylo porovnáno s provozem na stechiometrickou směs. Byla provedená detailní termodynamická analýza záznamu průběhu tlaku ve válci a byl vyhodnocen a analyzován průběh hoření. Výsledky naznačují potenciál ke zlepšení účinnosti motoru a současně možnost významného snižení emise $\mathrm{NO}_{\mathrm{x}} \mathrm{v}$ surových spalinách v porovnání se spalováním homogenní stechiometrické směsi.

KLÍČOVÁ SLOVA: CHUDÁ KONCEPCE, RECIRKULACE SPALIN, VÝVIN TEPLA, EMISE NO

\section{ABSTRACT}

An experimental investigation of homogeneous mixture combustion in a natural gas fuelled spark ignition engine at low load operation is presented in the paper. The low energy density of the mixture is a well-known limiting factor for the peak cycle temperature during combustion of the homogeneous mixture in spark ignition (SI) engines.

The most exact approach for description of fully optimized implementation of mixture dilution with a conventional combustion system is presented. This is a starting point for comparison with an advanced combustion system being prepared as the next step in ongoing research activity. The two methods of mixture dilution: 1) air dilution, and 2) cooled exhaust gas recirculation (EGR) are compared with the stoichiometric operation. Real-world data are presented, taking into account constraints observed on a particular engine. Detailed thermodynamic analysis of the cylinder pressure traces is performed and the combustion rates are evaluated and analyzed. The results show an increase in engine thermal efficiency (up to 7\%) together with a significant reduction of nitrogen oxides $\left(\mathrm{NO}_{\mathrm{x}}\right.$ ) emissions (up to $70 \%$ ) in raw exhaust gas compared to the homogeneous stoichiometric spark ignition operation, which is a conventional combustion strategy. Advanced combustion systems can further extend the improvement in both efficiency and $\mathrm{NO}_{x}$ emissions.

\section{KEYWORDS: LEAN BURN ENGINE, EXHAUST GAS RECIRCULATION, HEAT RELEASE, NO EMISSIONS}

\section{INTRODUCTION}

The diluted mixture is a well-known factor limiting the peak cycle temperature during the combustion of homogeneous mixture in spark ignition (SI) engines. Either high values of excess air ratio $(\lambda)$ or exhaust gas recirculation (EGR) are used for the practical implementation of this idea.

An extremely high excess air ratio value near the flammability limit enables achievement of low $\mathrm{NO}_{x}$ content in raw exhaust gas. This strategy, called the lean burn concept (LB), is frequently used in stationary natural gas fueled engines across the whole operating range. Stationary engines comply with the relevant emission regulations without exhaust gas aftertreatment. Heavy duty transportation engines, especially those converted from diesel engines to natural gas fueled $\mathrm{SI}$, also use the lean burn concept.

However, the lean burn concept exhibits certain drawbacks. If lean mixture is implemented, the achievable power needs to be compensated by increased boost pressure. Low burning velocity of the lean mixture additionally reduces $\mathrm{NO}_{x}$ formation, but it also worsens engine efficiency, especially if not compensated by optimized combustion phasing [1]. Poor flammability of the 
lean mixture causes high cycle-to-cycle variability. Lean burn strategy is frequently burdened by an excessive increase in exhaust hydrocarbons, which worsens the chemical efficiency of the engine [2]. Therefore, the stoichiometric concept is currently preferred in light duty vehicle engines, and this also extends to the area of the heavy duty engines (e.g. [3]), even if it does not represent the optimum solution for energy conversion. However, the mentioned drawbacks show little or no relevance as far as low $\mathrm{SI}$ engine load is concerned. A low mixture calorific value is even advantageous because it requires higher delivery of working substance for the given power demand, and therefore it decreases the pumping losses.

EGR is another strategy for mixture dilution. There are several reasons for implementation of EGR. Apart from a steep reduction of $\mathrm{NO}_{x}$ formation during diesel combustion (which is not a topic of the article), the limitation of the cylinder charge temperature by EGR delivery is suitable for dealing with selected challenges in the area of SI engines. In highly boosted SI engines with a stoichiometric concept $(\lambda=1)$ the EGR protects the engine parts against overheating and the working substance against autoignition in end gas layer (thus knock tendency is suppressed). The restriction of $\mathrm{NO}_{x}$ formation is even more effective than in the case of a lean burn concept because the dilutive agent contains little or no oxygen. As with the lean burn concept, the appearance of EGR in the cylinder charge decreases the pumping losses at low load.

The present work describes the trends in efficiency and emissions, and their intensity caused by the mixture dilution using both air and EGR as the dilutive substance at low engine load. The article describes the performance of a conventional means of mixture preparation and ignition as the starting point for a future comparison with advanced combustion systems, which are being developed by the authors. Evaluation of the impact of both LB and EGR dilution strategies is based on experimental investigation of the mentioned phenomenon.

\section{EXPERIMENTAL SETUP}

\section{I UNIT UNDER TEST}

A $4 \times \varnothing 102 / 120$ natural gas fuelled turbocharged SI engine was used as the test subject. The detailed test setup description can be found in Figure 7. It is equipped with a central mixer for metering and delivery of gaseous fuel into the compressor inlet. It is possible to manually control fuel flow or to operate with closed loop $\lambda$-control using conventional $\lambda$-sensor voltage as a feedback. A cooled low pressure EGR duct is equipped with a (servo driven) butterfly valve for proportional adjustment of EGR rate and with a manually controlled valve enabling complete interruption of the EGR delivery. Boost pressure control is performed using variable turbine geometry. Mixture inflow is controlled by a conventional throttle located downstream of the intercooler and actuated by a stepper. A well-proven high energy ignition system is installed to ensure sufficient spark energy. Ignition timing is controlled by an in-house designed and programmed source of triggering pulses, which enables digital adjustment of spark discharge with a resolution of 0.25 degrees crank angle (CA).

All actuators and a selected set of sensors are connected to the engine electronic control unit (ECU) specially developed in the author's department using a Field-Programmable-Gate-Array as a hardware (HW) platform. The ECU is fully accessible and allows an open loop control.

\subsection{DATA ACQUISITION}

The test engine is coupled to a direct current (DC) dynamometer. Information on engine speed and torque is transferred from the dynamometer ECU via an appropriate interface. A set of quite conventional pressure and temperature sensors is used for measurement of state conditions of the engine working substance as well as the coolant and the lube oil. Fuel consumption was measured using a volumetric flowmeter with rotating pistons. Fuel flow is recalculated on-line for normal conditions according to the pressure and temperature measured directly inside the flowmeter swept volume.

A set of laboratory exhaust gas analyzers $\left(\mathrm{CO}, \mathrm{CH}_{4^{\prime}}, \mathrm{CO}_{2^{\prime}}, \mathrm{NO}-\right.$ non dispersive infrared analyzers, $\mathrm{O}_{2}$ - paramagnetic detector), was used for continual analysis of exhaust gas. Air excess value was evaluated from mass balance equations using exhaust gas analysis results as calculation inputs. A second set of analyzers $\left(\mathrm{CO}, \mathrm{CH}_{4^{\prime}}\right.$ $\mathrm{CO}_{2^{\prime}}$ - non dispersive infrared analyzers, $\mathrm{NO}, \mathrm{NO}_{2}$ - non dispersive ultraviolet analyzer, $\mathrm{O}_{2}$ - paramagnetic detector) sampled the working substance from the intake manifold downstream of the intercooler. The analysis results were used for determination of EGR rate (if relevant) and for confirmation of calculated air excess value merely by determination of the ratio between measured values of the molar fraction of oxygen and methane.

All information acquired by the particular measuring chains were collected, preprocessed and recorded with a low speed data acquisition system.

In-cylinder pressure was sensed by an uncooled piezoelectric transducer installed in the glow plug hole of the cylinder head in cylinder \#1. The sensor signal conditioned by a charge amplifier was connected to the analogue input of a high speed data acquisition module. Two other analogue channels of the high speed acquisition system acquired signals from two inductive proximity sensors, to define actual instantaneous crankshaft position. These two signals were exploited for resampling of timeindexed signals to angle-resolved ones. Corresponding procedures and their implementation are described in detail in [5] and [6]. 


\subsection{EXPERIMENTAL PROCEDURE}

As was already mentioned in the introduction, engine operation at low load is the subject of investigation. An engine speed of $1800 \mathrm{rpm}$ and 3 bar brake mean effective pressure (BMEP) were chosen as representative values for low load operation. Natural gas from a public grid was used as a fuel. The VTG actuator was kept permanently in a position for maximum stator blades crosssectional area (= minimum boost pressure, which corresponds to the typical adjustment at low engine load).

The starting point for each measuring sequence was adjusted to the above-mentioned speed and load, $\lambda=1$, and angle position of normalized heat release value of $50 \%=10^{\circ}$ crank angle after compression top dead center (CA50 $=10^{\circ} \mathrm{CA}$ aTDC) in accordance with the optimum combustion phasing mentioned in [1].

The closed loop $\lambda$-control was running and was responsible for mixture strength adjustment at the starting point. For EGR sweep for subsequent operating points the air excess value was maintained by $\lambda$-control (i.e., $\lambda=1$ for all operating points) and EGR rate was increased in steps. For each value of EGR rate, the engine load was adjusted by manipulation of the intake throttle to demanded constant value (BMEP = 3 bar), and ignition timing was adjusted to maintain the condition CA50 $=10^{\circ} \mathrm{aTDC}$. EGR

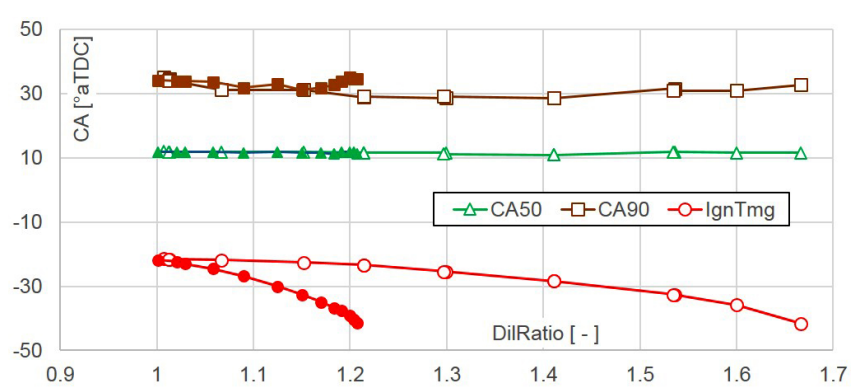

FIGURE 1: Combustion Phasing, coloured marks correspond to the EGR dilution, white marks correspond to the lean burn condition OBRÁZEK 1: Časování průběhu hoření, vybarvené body odpovídají režimům s recirkulací spalin, značky bez výplně odpovídají chudé koncepci

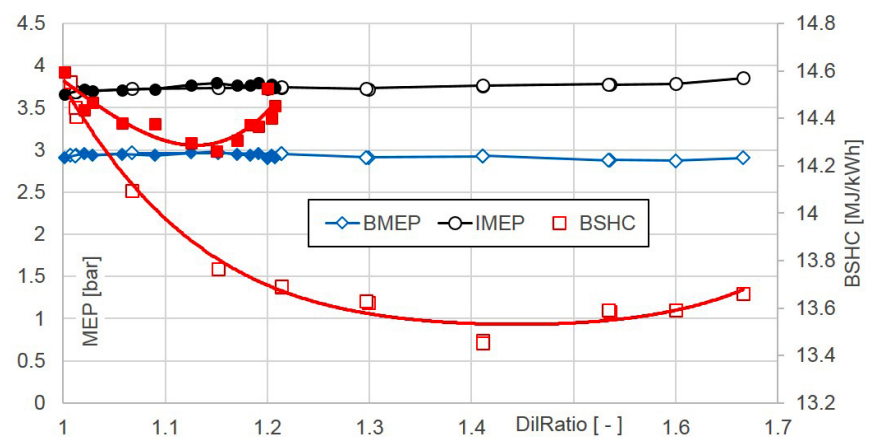

FIGURE 2: Engine power and efficiency, coloured marks correspond to the EGR dilution, white marks correspond to the lean burn condition OBRÁZEK 2: Energetické parametry motoru, vybarvené body odpovídají režimům s recirkulací spalin, značky bez výplně odpovídají chudé koncepci rate was increased until the occurrence of occasional misfiring was observed. The EGR coolant temperature was kept constant at $85^{\circ} \mathrm{C}$ (the same as engine coolant temperature).

During investigation of lean burn operation the actuator of $\lambda$-control at the starting point was adjusted manually to a position as close as possible to that which would be set by closed loop $\lambda$-control if it were running. It was verified that both the throttle position for BMEP = 3 bar and the exhaust gas composition had values very close to those obtained with the $\lambda$-control running. Therefore, the staring points for both measuring sequences (EGR and LB) were equivalent. The EGR line was completely closed using a manually controlled valve during $L B$ operation. Air excess value was increased in steps whilst maintaining BMEP $=3$ bar and CA50 $=10^{\circ}$ aTDC until misfiring was observed.

For both tests the coolant temperature at intercooler inlet were kept constant at $31^{\circ} \mathrm{C}$.

The position of CA50 was determined from the heat release (HR) curve integrated from on-line calculation of the Rate-ofHeat-Release using the simplified equation described in [2]. This equation can be evaluated as stand-alone using only data accessible within record from in-cylinder pressure indication. However, it assumes constant value of Poisson's constant and it neglects the heat transfer to the walls.

Within the framework of off-line detailed evaluation, an inverse algorithm for determination of HR scope was used which is based on exact implementation of the $1^{\text {st }}$ law of thermodynamics taking into account the temperature relationship of specific heat and heat transfer to the walls.

The physical quantity termed Dilution Ratio (DilRatio in the graphs) was used as an independent variable for graphical representations. It is directly equal to air excess value in the LB case and it is determined as: 1 + molar fraction of EGR in the intake.

\section{RESULTS AND DISCUSSION}

Figure 1 demonstrates how the condition $\mathrm{CA} 50=10^{\circ} \mathrm{CA}$ aTDC was accomplished and describes the necessary shift of ignition timing (IgnTmg in the figure). Information about combustion phasing is completed by curves of CA90, which offer an assessment of late-phase combustion duration. It is obvious that both means of charge dilution cause reduction in burning velocity, particularly in the early stage of the combustion process. At the misfiring limit the same spark advance is demanded for both investigated cases.

Engine power and efficiency are presented in Figure 2. The curves of BMEP and indicated mean effective pressure (IMEP) demonstrate the accuracy of adjustment of demanded BMEP value and the reproducibility of friction losses. The scope of brake specific heat consumption (BSHC) is plotted in this figure as well. 


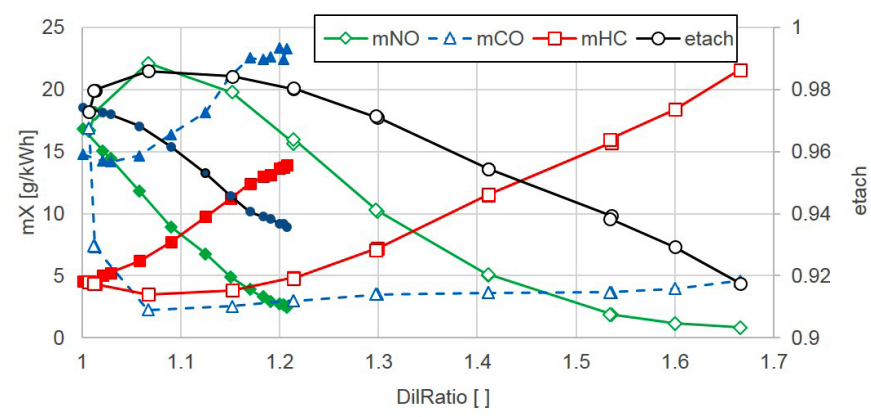

FIGURE 3: Specific production of pollutants, coloured marks correspond to the EGR dilution, white marks correspond to the lean burn condition OBRÁZEK 3: Měrná emise škodlivin, vybarvené body odpovídají režimům s recirkulací spalin, značky bez výplně odpovídají chudé koncepci

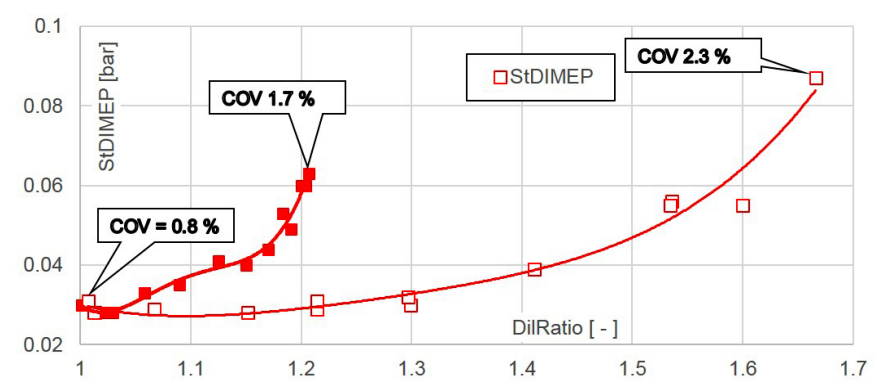

FIGURE 4: IMEP variability, coloured marks correspond to the EGR dilution, white marks correspond to the lean burn condition OBRÁZEK 4: Variabilita středního indikovaného tlaku, vybarvené body odpovídají režimům s recirkulací spalin, značky bez výplně odpovídají chudé koncepci
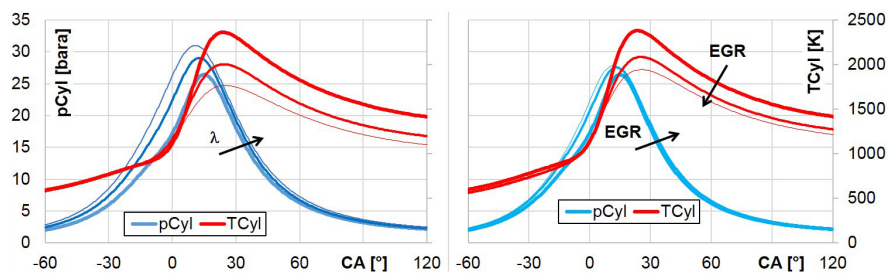

FIGURE 5: Impact of charge dilution on cylinder pressures and temperatures, lean burn (left), EGR (right)

OBRÁZEK 5: Vliv zředění náplně na tlak a teplotu ve válci, vlevo chudá koncepce, vpravo recirkulace spalin

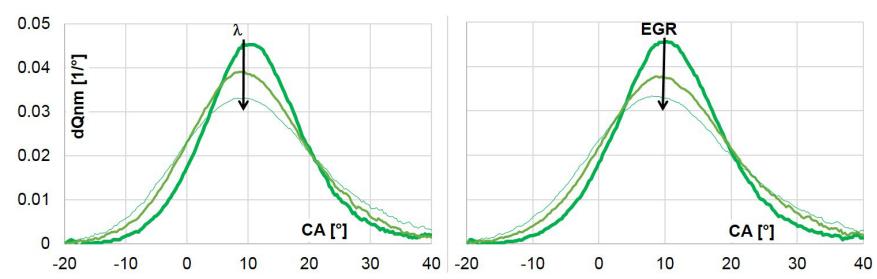

FIGURE 6: Rates of heat release, lean burn (left), EGR (right) OBRÁZEK 6: Rychlost vývinu tepla, vlevo chudá koncepce, vpravo recirkulace spalin
If combustion phasing is adjusted to the optimum state, the mixture dilution offers improvement in engine efficiency. This is especially valid for air dilution. The measured positive effect of the mixture dilution is in accordance with the theoretical study presented by Lavoie et al. [1]. Experimental data shows a less significant effect in the case of EGR, which is probably caused by chemical efficiency as shown in Figure 3. The theoretical study [1] did not take the chemical efficiency into account and therefore shows approximately equal significance of both means of dilution.

The raw exhaust gas composition is the next relevant output. In Figure 3 the specific production of monitored pollutants is introduced as calculated from their molar fraction in the raw exhaust gas, the exhaust gas flow and the effective power. The formation of the products of incomplete combustion in the case of EGR dilution rises continuously and steeply from the beginning. Correspondingly, the chemical efficiency is negatively influenced as shown by the black lines with circle marks in Figure 3. Reduction of $\mathrm{NO}_{x}$ content in raw exhaust gases is significant; however, it is still insufficient when compared with the latest legislative demands valid for vehicle application.

Another aspect of dilution mixture is an increase of cycle-tocycle variability of engine performance. Figure 4 represents this phenomena by means of the Standard Deviation of IMEP derived from records of 160 consecutive cycles at each operating point. At both ends of the curves, the values of the Coefficient of Variation (COV) of IMEP are displayed. The limit values of the COV are surprisingly low, especially when compared with data presented by Heywood et al. [2]. The range of the dilution was limited by the occasional occurrence of misfiring, even if the running roughness is well below $\mathrm{COV}_{\text {IMEP }} 10 \%$, which is a value mentioned in e.g. [2] as a limit of stability.

Crank angle indexed data are introduced in Figure 5 in the form of cylinder pressure and temperature in averaged cycles. Two limit operational points for both air and EGR dilution are plotted and completed with a plot from a cycle approximately in the middle of the range. In accordance with expectations, in-cylinder temperature during the high pressure range of the engine working cycle decreases with increasing dilution. Pressure increase with increased dilution is caused by demand for increase in cylinder charge mass to maintain constant BMEP.

Burning velocity is demonstrated by curves of rate of heat release in Figure 6. Data originates from the same operational points as in Figure 5. Even if the peak value of the RoHR decreases with increased dilution, the position of the peak is approximately constant thanks to the adjusted spark timing. 


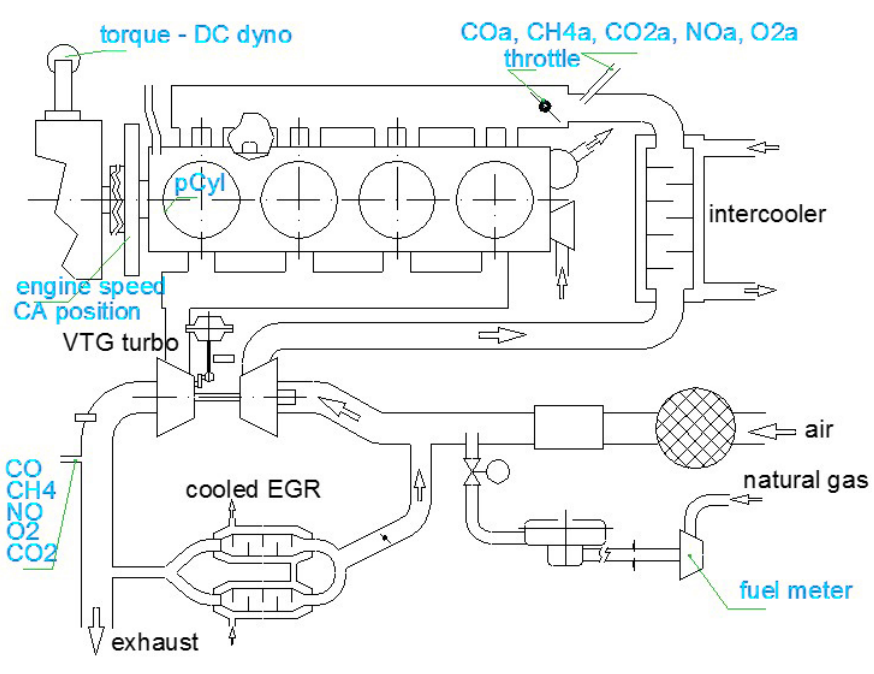

FIGURE 7: Testing engine layout and data acquisition schematic OBRÁZEK 7: Uspořádání testovaného motoru a schéma sběru dat

\section{SUMMARY AND CONCLUSION}

Experimental investigation was performed in order to assess the achievable performance of dilution mixture at low load using conventional SI engine design and accessory layout. Combustion phasing was carefully optimized to compensate for slow burning of diluted mixture.

The range of mixture dilution is limited by misfire occurrence at $20 \%$ of EGR rate, or approximately $\lambda=1.65$ in the case of air dilution.

Brake efficiency of the engine can be improved compared to the base point $(\lambda=1, E G R=0)$ by $7 \%$ with optimal air dilution, and $2 \%$ with optimal EGR.

It is impossible to reach the levels of pollutant emissions compatible with the latest legislative requirements without exhaust gas aftertreatment. From this point of view the advantage of the EGR mixture dilution to the lean burn strategy is the ability to use the well proven three way catalytic exhaust gas aftertreatment.

The reference data were acquired for a future comparison with advanced combustion and mixture preparation concepts. Innovative combustion systems are currently being elaborated within the framework of running projects at the author's institute.

\section{ACKNOWLEDGEMENTS}

This research has been realized using the support from the Grant Agency of the Czech Technical

University in Prague, grant No. SGS13/184/OHK2/3T/12 and under the support of the Ministry of Education, Youth and Sports Program NPU I (LO), Project \# L01311 Development of Vehicle Centre of Sustainable Mobility. This support is gratefully acknowledged.
LIST OF NOTATIONS AND ABBREVIATIONS

BMEP brake mean effective pressure

BSHC brake specific heat consumption

CA crank angle

CO carbon monoxide

COV coefficient of variation

ECU electronic control unit

EGR exhaust gas recirculation

etach chemical efficiency

HC hydrocarbons

HR heat release

HW hardware

IgnTmg ingition timing

IMEP indicated mean effective pressure

$\lambda \quad$ air excess ratio

LB lean burn

$\mathrm{m}$ specific mass production

NO nitric oxide

$\mathrm{NO}_{x} \quad$ nitrogen oxide

$\mathrm{PCyl}$ cylinder pressure

RoHR,

$\mathrm{dQnm}$ rate of heat release

SI spark ignition

StD standard deviation

TCyl cylinder temperature

VTG variable turbine geometry

\section{REFERENCES}

[1] LAVOIE, G.A., ORTIZ-SOTO, E., BABAJIMOPOULOS, A., MARTZ, J.B., ASSANIS, D.N. Thermodynamic sweet spot for high efficiency, dilute, boosted gasoline engines, (2013) International Journal of Engine Research, 14 (3), pp. $260-278$

[2] HEYWOOD J. B., Internal Combustion Engine Fundamentals, McGraw-Hill Science/Engineering/Math; 1 edition (April 1, 1988), ISBN-10: 007028637X, ISBN-13: 978-0070286375

[3] VODSTRČIL, J., Alternativy pohonu autobusu. In: Autosympo 2013

[4] VAVRA, J., TAKATS, M., KLIR, V., AND SKAROHLID, M., "Influence of Natural Gas Composition on Turbocharged Stoichiometric SI Engine Performance," SAE Technical Paper 2012-01-1647, 2012, doi:10.4271/2012-01-1647.

[5] TAKÁTS, M., Low Cost Angle Calculator, in Journal of Middle European Construction and Design of Cars, MECCA, Volume 10, Issue 3 (Dec 2012), doi: 10.2478/v10138-012-0018-4

[6] TAKÁTS, M., VÁVRA, J. SW Tool for Generation of AngleResolved Record of Fast Changing Physical Quantities, in proceedings of KOKA 2013. 